\title{
Local Anaesthetic Infiltration in Joint Replacement Surgery: What Is Its Role in Enhanced Recovery?
}

\author{
Ian Starks, ${ }^{1}$ Tom Wainwright, ${ }^{1,2}$ and Robert Middleton ${ }^{1,2}$ \\ ${ }^{1}$ The Royal Bournemouth Hospital, Bournemouth BH7 7DW, UK \\ ${ }^{2}$ Centre of Postgraduate Medicine, Research \& Education, The School of Health and Social Care, Bournemouth University, \\ Bournemouth BH1 3LT, UK
}

Correspondence should be addressed to Ian Starks, ianstarks@doctors.org.uk

Received 4 October 2011; Accepted 20 October 2011

Academic Editors: C.-R. Lin and M. Şentürk

Copyright (c) 2011 Ian Starks et al. This is an open access article distributed under the Creative Commons Attribution License, which permits unrestricted use, distribution, and reproduction in any medium, provided the original work is properly cited.

\begin{abstract}
The last 10 years has seen the increased use of enhanced recovery pathways across several surgical specialities. A prerequisite of enhanced recovery is the ability to mobilise patients early. This is dependent upon good postoperative pain control. A number of different techniques have been employed in joint replacement surgery to address this issue. This paper focuses upon the current evidence for local infiltration anaesthesia.
\end{abstract}

\section{Introduction}

The last decade has seen the growing use of enhanced recovery pathways (also known as "fast-track," "rapid recovery," and "accelerated rehabilitation") across several surgical specialities including orthopaedics. Such techniques, originally described in colorectal surgery, have been shown to both improve patient care and reduce length of stay in general populations undergoing surgery [1-4]. This has huge implications in terms of health care savings.

These pathways focus on optimising every aspect of the patient's journey, promoting the patient as an active participant in their own recovery process and rehabilitation. They involve a multidisciplinary, evidence-based approach and focus on patient education in addition to surgical and anaesthetic techniques [1]. At the core of enhanced recovery is the ability to mobilise patients early. Effective perioperative analgesia is thus an essential component of any enhanced recovery pathway and starts with the choice of anaesthetic. There has been a shift towards the use of regional anaesthesia over general anaesthesia in joint replacement surgery [5]. Whilst general anaesthesia has a lower incidence of hypotension postoperatively, regional anaesthesia is not only associated with reduced nausea postoperatively but may also have the additional benefit of a reduced risk of deep vein thrombosis, pulmonary embolus, myocardial infarction, pneumonia, and delirium [6-10]. However, this remains an area in which further research is needed. Postoperatively the use of standardised analgesic ladders has been seen to be effective in reducing excessive or inappropriate opiate consumption again aiding early mobilisation.

In order to optimise pain control in the early postoperative period, a number of adjuncts have been tried. These include peripheral nerve blocks (e.g., femoral, combined femoral and sciatic, and lumbar plexus blocks) and local anaesthetic infiltration to the joint or the wound. These techniques may involve single administration of local anaesthetic (possibly combined with other analgesic agents) or continuous infusion/bolus for 24 to 48 hours postoperatively. Variable results have been reported [5, 11-14]. For the purpose of this paper we intend to focus solely on the role of local anaesthetic infiltration in hip and knee replacement surgery. Following a current literature search of the Pubmed and Cochrane databases using the search terms "hip replacement," "hip arthroplasty," "knee replacement," "knee arthroplasty," and "local anaesthetic," English language randomised controlled trials were identified from the literature (Tables 1 and 2).

The drive to develop safe and effective opioid-sparing analgesic regimens whilst avoiding the potential complications of peripheral nerve blocks [33] has resulted in increased focus upon the role of local anaesthetic infiltration in joint 
TABLE 1: Overview of the literature summarising study design.

\begin{tabular}{|c|c|c|c|c|c|c|}
\hline Author & Study design & $n$ & $\begin{array}{c}\text { Joint } \\
\text { replacement }\end{array}$ & Anaesthesia & Analgesia: study group & Control \\
\hline Vendittoli et al. [14] & RCT & 42 & Knee & Spinal & $\begin{array}{l}\text { LIA + PCA ( } 275 \mathrm{mg} \text { ropivacaine, } \\
30 \mathrm{mg} \text { ketorolac, adrenaline) plus } \\
150 \mathrm{mg} \text { ropivacaine at } 24 \mathrm{hrs}\end{array}$ & PCA \\
\hline Kerr and Kohan [15] & Case series & 325 & Hip and Knee & $\begin{array}{l}\text { Majority } \\
\text { Spinal }\end{array}$ & $\begin{array}{l}\text { LIA ( } \max 300 \mathrm{mg} \text { ropivacaine, } \\
30 \mathrm{mg} \text { ketorolac, adrenaline) plus } \\
\text { reinjection at } 15-20 \mathrm{hrs}\end{array}$ & N/A \\
\hline Andersen et al. [16] & RCT & 40 & Hip & Spinal & $\begin{array}{l}\text { LIA + PCA ( } 300 \text { mg ropivacaine, } \\
30 \text { mg ketorolac, adrenaline) plus } \\
\text { reinjection next morning }\end{array}$ & PCA \\
\hline Busch et al. [17] & RCT & 64 & Knee & $\begin{array}{l}\text { General or } \\
\text { regional }\end{array}$ & $\begin{array}{l}\text { LIA + PCA ( } 400 \mathrm{mg} \text { ropivacaine, } \\
30 \mathrm{mg} \text { ketorolac, } 5 \mathrm{mg} \\
\text { epimorphine, adrenaline) }\end{array}$ & PCA \\
\hline Essving et al. [18] & RCT & 48 & Knee & General & $\begin{array}{l}\text { LIA + PCA ( } 400 \mathrm{mg} \text { ropivacaine, } \\
30 \mathrm{mg} \text { ketorolac, adrenaline) plus } \\
\text { reinjection at } 21 \mathrm{hrs}\end{array}$ & PCA \\
\hline $\begin{array}{l}\text { Gómez-Cardero and } \\
\text { Rodríguez-Merchán [19] }\end{array}$ & RCT & 50 & Knee & Spinal & $\begin{array}{l}\text { LIA (continuous intra-articular } \\
\text { infusion } 300 \mathrm{mls} \text { of } 0.2 \% \\
\text { ropivacaine at } 5 \mathrm{ml} / \mathrm{hr} \text { until } \\
\text { empty) }\end{array}$ & Saline infusion \\
\hline Krenzel et al. [20] & RCT & 66 & Knee & Spinal & $\begin{array}{l}\text { CFNB + posterior capsule } \\
\text { injection + PCA ( } 20 \mathrm{ml} \mathrm{0.2 \%} \\
\text { ropivacaine) }\end{array}$ & $\mathrm{CFNB}+\mathrm{PCA}$ \\
\hline Andersen et al. [21] & RCT & 12 & $\begin{array}{c}\text { Knee } \\
\text { (bilateral) }\end{array}$ & Spinal & $\begin{array}{l}\text { LIA + PCA ( } 340 \mathrm{mg} \text { ropivacaine, } \\
\text { adrenaline) plus reinjection at } 8 \\
\text { and } 24 \mathrm{hrs}\end{array}$ & PCA \\
\hline Zhang et al. [22] & RCT & 80 & Knee & General & $\begin{array}{l}\text { LIA ( } 300 \mathrm{mg} \text { ropivacaine, } 30 \mathrm{mg} \\
\text { ketorolac, adrenaline) plus } 48 \mathrm{hrs} \\
\text { continuous infusion } \\
\text { (ropivacaine, ketorolac) }\end{array}$ & $\begin{array}{l}\text { Control 1: LIA } \\
\text { ( } 300 \mathrm{mg} \\
\text { ropivacaine, } 30 \mathrm{mg} \\
\text { ketorolac, } \\
\text { adrenaline) plus } \\
\text { saline infusion } \\
\text { Control 2: saline } \\
\text { infusion }\end{array}$ \\
\hline Chen et al. [23] & RCT & 92 & Hip & General & $\begin{array}{l}\text { LIA + PCA ( } 24 \mathrm{mls} 0.5 \% \\
\text { bupivacaine) plus continuous } \\
\text { infusion } 2 \mathrm{ml} / \mathrm{hr}\end{array}$ & PCA \\
\hline Andersen et al. [24] & RCT & 16 & $\begin{array}{c}\text { Knee } \\
\text { (bilateral) }\end{array}$ & Spinal & $\begin{array}{l}\text { LIA + PCA ( } 300 \mathrm{mg} \text { ropivacaine, } \\
\text { adrenaline) plus reinjection } \\
24 \mathrm{hrs}\end{array}$ & PCA \\
\hline Andersen et al. [25] & RCT & 32 & Knee & Spinal & $\begin{array}{l}\text { LIA ( } 170 \text { mls } 0.2 \% \text { ropivacaine } \\
\text { and adrenaline) }+ \text { intra- and } \\
\text { extra-articular injection } \\
\text { ropivacaine and adrenaline at } \\
24 \text { hrs }\end{array}$ & $\begin{array}{l}\text { LIA ( } 170 \text { mls } 0.2 \% \\
\text { ropivacaine and } \\
\text { adrenaline) }+ \\
\text { intra-articular } \\
\text { injection } \\
\text { ropivacaine and } \\
\text { adrenaline only at } \\
24 \text { hrs }\end{array}$ \\
\hline Spreng et al. [26] & RCT & 102 & Knee & Spinal & $\begin{array}{l}\text { LIA + PCA ( } 150 \mathrm{mg} \text { ropivacaine } \\
\text { and adrenaline), subgroup with } \\
30 \mathrm{mg} \text { ketorolac and } 5 \mathrm{mg} \\
\text { morphine } \\
\text { Reinjection } 24 \mathrm{hrs}\end{array}$ & Epidural + PCA \\
\hline Andersen et al. [27] & RCT & 80 & Hip & Spinal & $\begin{array}{l}\text { LIA ( } 200 \mathrm{mg} \text { ropivacaine, } 30 \mathrm{mg} \\
\text { ketorolac, adrenaline) plus } \\
\text { intra-articular injection at } 8 \mathrm{hrs}\end{array}$ & Epidural \\
\hline
\end{tabular}


Table 1: Continued.

\begin{tabular}{|c|c|c|c|c|c|c|}
\hline Author & Study design & $n$ & $\begin{array}{c}\text { Joint } \\
\text { replacement }\end{array}$ & Anaesthesia & Analgesia: study group & Control \\
\hline Andersen et al. [28] & RCT & 40 & Knee & Spinal & $\begin{array}{l}\text { LIA + PCA ( } 300 \text { mg ropivacaine, } \\
30 \text { mg ketorolac, adrenaline) plus } \\
\text { continuous intra-articular } \\
\text { infusion (ropivacaine, ketorolac) }\end{array}$ & Epidural + PCA \\
\hline Thorsell et al. [29] & RCT & 85 & Knee & $\begin{array}{l}\text { Spinal or } \\
\text { epidural }\end{array}$ & $\begin{array}{l}\text { LIA ( } 300 \mathrm{mg} \text { ropivacaine, } 30 \mathrm{mg} \\
\text { ketorolac, adrenaline) plus } \\
\text { further injection day } 1 \\
\text { (bupivacaine-adrenaline) }\end{array}$ & Epidural \\
\hline Toftdahl et al. [30] & RCT & 80 & Knee & Spinal & $\begin{array}{l}\text { LIA ( } 300 \mathrm{mg} \text { ropivacaine, } 30 \mathrm{mg} \\
\text { ketorolac, adrenaline) plus } \\
\text { intra-articular injection at } 10 \mathrm{pm} \\
\text { and } 10 \mathrm{am}\end{array}$ & CFNB \\
\hline Carli et al. [31] & RCT & 40 & Knee & Spinal & $\begin{array}{l}\text { LIA + PCA ( } 300 \text { mg ropivacaine, } \\
45 \mathrm{mg} \text { ketorolac, adrenaline) plus } \\
\text { intra-articular injectionat } 24 \mathrm{hrs}\end{array}$ & $\mathrm{CFNB}+\mathrm{PCA}$ \\
\hline Affas et al. [32] & RCT & 40 & Knee & Spinal & $\begin{array}{l}\text { LIA + PCA ( } 300 \text { mg ropivacaine, } \\
30 \text { mg ketorolac, adrenaline) plus } \\
\text { intra-articular infusion at } 24 \mathrm{hrs}\end{array}$ & $\mathrm{FNB}+\mathrm{PCA}$ \\
\hline
\end{tabular}

LIA: local infiltration analgesia, RCT: randomized controlled trial, PCA: patient controlled analgesia, (C)FNB: (continuous) femoral nerve block, LOS: length of stay.

replacement surgery. This is a technique that has been developed in part by Kohan and Kerr in Sydney, Australia, and involves the infiltration of the surgical site with a high volume of a long-acting local anaesthetic agent $(+/-$ analgesic agents) with adrenaline $[15,34]$. Theoretically, it seems logical to block the pain signal at the site of nociceptive stimulus, that is, the surgical site [35]. This technique has the additional benefits of being simple with a low side effect profile.

There is a growing body of evidence to support the use of local infiltration techniques. Whilst early reports often consisted of case series, the last five years has seen a growing number of randomised controlled trials $[14,16-24,36]$. The majority advocate the use of local infiltration in knee replacement surgery with more limited evidence supporting its use during hip replacement. Most studies observed a reduction in early postoperative pain and opiate use, along with a tendency towards reduced length of stay, without an increased risk of complications. Most studies use a multimodal infiltration approach in which the use of a high volume of longacting local anaesthetic agent, typically ropivacaine (longer acting than bupivacaine with less cardiac and central nervous system toxicity) is combined with analgesics (NSAIDs and/or opiates) and adrenaline. The use of adrenaline is thought to improve the efficacy of the local anaesthetic and reduces the toxicity, by helping to keep it localised to the injection site. The addition of opiates targets the opioid receptors activated as a result of the surgical trauma [37], and nonsteroidal anti-inflammatory drugs (NSAIDs) also help to reduce local production of inflammatory mediators both acting as adjuncts to the local anaesthetic.

Busch et al. [17] performed a prospective, blinded, randomized, controlled trial on 64 patients undergoing unilateral knee replacement surgery. Patients were randomized to receive either a multimodal infiltration consisting of ropivacaine, ketorolac, epimorphine, and adrenaline or no injection. In the study group they observed a significant reduction in patient controlled analgesic use over the first 24 hours and improved patient satisfaction. However, no difference in range of motion or length of stay was observed. No adverse events were observed in the study group.

Anderson et al. [16] undertook a prospective randomised, double-blind, controlled trial to investigate the effect of local infiltration followed by continuous intraarticular infusion for 24 hours postoperatively in 37 patients undergoing hip replacement surgery. The study group received local infiltration of ropivacaine, ketorolac, and adrenaline followed by an intra-articular infusion of the same three drugs for 24 hours postoperatively. The control group received saline solution in equal volumes to the study group. The study group reported less pain for the first 2 weeks postoperatively and reduced breakthrough analgesic requirements. This was associated with significantly less joint stiffness and better physical function, but whilst there was a trend towards earlier discharge in the study group, this was not statistically significant. Again, no adverse events were reported in the study group.

However, there are several drawbacks to both these studies and others looking at the role of local anaesthetic infiltration in joint replacement surgery. The sample sizes involved are relatively small, and power analysis was seldom performed. Thus they should be interpreted with caution (Tables 1 and 2). This is especially the case in the nonblinded studies where observational bias may play a role. It also makes drawing negative conclusions difficult, such as "no adverse events," "no reduction in length of stay," or "no increased risk of infection" as large study groups are often 
TABLE 2: Overview of the literature summarising study outcome measures, results, and conclusions.

\begin{tabular}{|c|c|c|c|}
\hline Author & Outcome measures & Results & Authors' conclusions \\
\hline Vendittoli et al. [14] & $\begin{array}{l}\text { Morphine consumption, } \\
\text { Pain control, } \\
\text { Medication-related side } \\
\text { effects }\end{array}$ & $\begin{array}{l}\text { Reduced morphine } \\
\text { consumption, pain scores, and } \\
\text { nausea with LIA }\end{array}$ & $\begin{array}{l}\text { Multimodal approach offers } \\
\text { improved pain control with } \\
\text { minimal side effects }\end{array}$ \\
\hline Kerr and Kohan [15] & $\begin{array}{l}\text { Pain scores, } \\
\text { Time to mobilisation, } \\
\text { LOS }\end{array}$ & $\begin{array}{l}\text { Satisfactory pain control,most } \\
\text { walk 5-6 hrs, } 71 \% \text { single } \\
\text { overnight stay }\end{array}$ & $\begin{array}{l}\text { Simple, safe, and effective for } \\
\text { pain management in hip and } \\
\text { knee surgery }\end{array}$ \\
\hline Andersen et al. [16] & $\begin{array}{l}\text { Opiate consumption, } \\
\text { Pain control, } \\
\text { Medication-related side } \\
\text { effects }\end{array}$ & $\begin{array}{l}\text { Reduced pain (up to } 2 \text { weeks) } \\
\text { and opiate consumption with } \\
\text { LIA, } \\
\text { No difference in LOS }\end{array}$ & $\begin{array}{l}\text { Reduces pain and the } \\
\text { requirements for analgesics after } \\
\text { hip replacement }\end{array}$ \\
\hline Busch et al. [17] & $\begin{array}{l}\text { PCA consumption, } \\
\text { Pain control }\end{array}$ & $\begin{array}{l}\text { Reduced PCA requirements first } \\
24 \mathrm{hrs} \text { and pain scores } 4 \mathrm{hrs}, \\
\text { No difference in LOS }\end{array}$ & $\begin{array}{l}\text { Reduces requirements for PCA } \\
\text { and improves satisfaction }\end{array}$ \\
\hline Essving et al. [18] & $\begin{array}{l}\text { Analgesic consumption, } \\
\text { Pain control, } \\
\text { LOS }\end{array}$ & $\begin{array}{l}\text { Reduced analgesic consumption } \\
\text { and pain scores, } \\
\text { Shorter time to home readiness } \\
\text { but no difference in LOS }\end{array}$ & $\begin{array}{l}\text { Excellent pain relief, lower } \\
\text { morphine consumption and } \\
\text { shorter time to home readiness }\end{array}$ \\
\hline $\begin{array}{l}\text { Gómez-Cardero and } \\
\text { Rodríguez-Merchán [19] }\end{array}$ & $\begin{array}{l}\text { Pain scores, } \\
\text { Opioid use, } \\
\text { Joint function, } \\
\text { LOS }\end{array}$ & $\begin{array}{l}\text { Lower pain scores and opioid use } \\
\text { first } 72 \mathrm{hrs} \\
\text { No difference in ROM, } \\
\text { Reduced LOS }\end{array}$ & $\begin{array}{l}\text { Effective in treating pain and } \\
\text { reducing opioid use and also } \\
\text { reduces mean LOS without } \\
\text { increased risk of complications }\end{array}$ \\
\hline Krenzel et al. [20] & $\begin{array}{l}\text { Pain scores, } \\
\text { Opioid use }\end{array}$ & $\begin{array}{l}\text { Reduced PCA use at first } 12 \mathrm{hrs} \\
\text { only }\end{array}$ & $\begin{array}{l}\text { Posterior capsular injection did } \\
\text { not improve pain or accelerate } \\
\text { recovery after } 12 \text { hrs in patients } \\
\text { receiving a CFNB }\end{array}$ \\
\hline Andersen et al. [21] & Pain in each leg & $\begin{array}{l}\text { Significant reduction in pain up } \\
\text { to } 32 \mathrm{hrs}\end{array}$ & $\begin{array}{l}\text { Effective, and due to simplicity, } \\
\text { may be preferable to other } \\
\text { analgesic techniques }\end{array}$ \\
\hline Zhang et al. [22] & $\begin{array}{l}\text { Pain scores, } \\
\text { Opioid use, } \\
\text { Joint function }\end{array}$ & $\begin{array}{l}\text { Lower pain scores ( } 8-48 \mathrm{hrs}) \text { and } \\
\text { opiate consumption ( } 24-48 \mathrm{hrs}) \\
\text { and improved flexion (days } 7 \\
\text { and } 90) \text { with LIA and continuous } \\
\text { infusion }\end{array}$ & $\begin{array}{l}\text { Continuous LIA provides } \\
\text { prolonged superior analgesia. It } \\
\text { is associated with more } \\
\text { favourable functional recovery }\end{array}$ \\
\hline Chen et al. [23] & Pain scores & $\begin{array}{l}\text { Longer time to first narcotic } \\
\text { rescue, } \\
\text { Lower pain scores at first } 2 \mathrm{hrs} \\
\text { only, } \\
\text { No difference in LOS }\end{array}$ & $\begin{array}{l}\text { Continuous intra-articular } \\
\text { infusion of bupivacaine does not } \\
\text { provide sustained pain relief }\end{array}$ \\
\hline Andersen et al. [24] & Pain scores & $\begin{array}{l}\text { Reduced pain at first } 6 \mathrm{hrs} \text { but } \\
\text { not at } 24 \mathrm{hrs}\end{array}$ & $\begin{array}{l}\text { Effective in early postoperative } \\
\text { pain relief but no improved } \\
\text { analgesia with } 24 \mathrm{hr} \text { bolus }\end{array}$ \\
\hline Andersen et al. [25] & Pain scores & $\begin{array}{l}\text { No significant difference between } \\
\text { groups }\end{array}$ & $\begin{array}{l}\text { Optimal site of administration of } \\
\text { LA cannot be determined from } \\
\text { this study }\end{array}$ \\
\hline Spreng et al. [26] & $\begin{array}{l}\text { Pain scores, } \\
\text { Rehabilitation, } \\
\text { Discharge readiness }\end{array}$ & $\begin{array}{l}\text { Lower pain scores initially in the } \\
\text { epidural groups. } \\
\text { Both LIA groups mobilised faster } \\
\text { and were ready for discharge } \\
\text { earlier }\end{array}$ & $\begin{array}{l}\text { LIA is effective when compared } \\
\text { to epidural analgesia. } \\
\text { Ketorolac and morphine are } \\
\text { more effective when given locally }\end{array}$ \\
\hline Andersen et al. [27] & $\begin{array}{l}\text { Pain scores, } \\
\text { Time to mobilisation, } \\
\text { LOS }\end{array}$ & $\begin{array}{l}\text { LIA group observed reduced } \\
\text { pain scores at } 20-96 \text { hrs, narcotic } \\
\text { consumption, and LOS with } \\
\text { increased early mobilisation }\end{array}$ & $\begin{array}{l}\text { LIA combined with } \\
\text { intra-articular injection can be } \\
\text { recommended in THA }\end{array}$ \\
\hline
\end{tabular}


Table 2: Continued.

\begin{tabular}{|c|c|c|c|}
\hline Author & Outcome measures & Results & Authors' conclusions \\
\hline Andersen et al. [28] & $\begin{array}{l}\text { Pain scores, } \\
\text { Medication-related side } \\
\text { effects, } \\
\text { LOS }\end{array}$ & $\begin{array}{l}\text { Reduced morphine consumption } \\
\text { and pain scores with LIA. } \\
\text { No difference in LOS but ready } \\
\text { for discharge earlier with LIA }\end{array}$ & $\begin{array}{l}\text { Provides superior pain relief and } \\
\text { reduced morphine consumption } \\
\text { compared with continuous } \\
\text { epidural infusion and } \\
\text { Offers advantages in its } \\
\text { simplicity and minimal risk of } \\
\text { complications }\end{array}$ \\
\hline Thorsell et al. [29] & $\begin{array}{l}\text { Pain scores, } \\
\text { Time to mobilisation, } \\
\text { LOS }\end{array}$ & $\begin{array}{l}\text { Lower pain scores and earlier } \\
\text { mobilisation with LIA } \\
\text { No difference LOS }\end{array}$ & $\begin{array}{l}\text { LIA is better for postoperative } \\
\text { pain relief after TKR then } \\
\text { epidural }\end{array}$ \\
\hline Toftdahl et al. [30] & $\begin{array}{l}\text { Pain scores, } \\
\text { Opioid consumption, } \\
\text { Time to mobilisation, } \\
\text { LOS }\end{array}$ & $\begin{array}{l}\text { Reduced pain scores during } \\
\text { physio and opioid consumption } \\
\text { on day } 1 \text { only, } \\
\text { no difference LOS }\end{array}$ & $\begin{array}{l}\text { This technique provides a good } \\
\text { quality of analgesia after TKR } \\
\text { without increased risk }\end{array}$ \\
\hline Carli et al. [31] & $\begin{array}{l}\text { Opiate consumption, } \\
\text { Functional walking } \\
\text { capacity, } \\
\text { Physical activity }\end{array}$ & $\begin{array}{l}\text { No difference in pain scores but } \\
\text { reduced opiate consumption } \\
\text { with FNB. } \\
\text { Physical activity and knee } \\
\text { function improved at } 6 \text { weeks } \\
\text { with FNB }\end{array}$ & $\begin{array}{l}\text { FNB is associated with lower } \\
\text { opioid consumption and a better } \\
\text { recovery at } 6 \text { weeks }\end{array}$ \\
\hline Affas et al. [32] & $\begin{array}{l}\text { Pain scores,opiate } \\
\text { consumption }\end{array}$ & $\begin{array}{l}\text { No difference in pain scores or } \\
\text { opiate consumption }\end{array}$ & $\begin{array}{l}\text { Both provide good analgesia after } \\
\text { TKR. } \\
\text { LIA is cheaper and easier to } \\
\text { perform }\end{array}$ \\
\hline
\end{tabular}

required to make such observations. In addition, the use of different multimodal anaesthetic regimens and different end points makes comparisons across studies difficult.

Thus whilst the growing body of evidence seems to support a role for the routine use of local anaesthetic agents in joint replacement surgery as part of a multimodal infiltration technique, a number of questions remain unclear.

\section{Single Dose or Continuous Infusion?}

Whilst Busch et al. [17] observed good outcomes using the single infiltration technique other studies have not supported this. Krenzel et al. [20] did not observe any additional benefit beyond 12 hours with a posterior capsular injection of ropivacaine during total knee arthroplasty (with CFNB) when compared with injection of saline. However, these differences may be as a result of the fact that Krenzel et al. [20] used only ropivacaine and infiltrated the posterior capsule alone. These observations may also support the important role of the other drugs used as part of the multimodal infiltration technique.

Concerns regarding the length of duration of action of the local anaesthetic agents have resulted in the use of continuous intra-articular infusions following local infiltration in hip and knee replacement surgery. The rationale being to maximise the benefit of postoperative pain relief in the early post operative period. This technique involves catheter placement by the surgeon at the end of the operation under aseptic conditions and the use of bacterial filters and closed infusion systems [18].
There are now a number of randomised controlled trials supporting the use of the high-volume infiltration combined with intra-articular infusion or further bolus dose $[16,18,19$, $21,22]$. However not all studies support the use of additional bolus doses or infusions $[23,24]$. The lack of any significant benefit observed by Chen et al. [23] may be due to the use of bupivacaine rather than ropivacaine. The increased cardiac and CNS toxicity of the former means lower doses must be used. Again, it may also reflect the synergistic action of the other drugs used as part of the multimodal infiltration technique. This is an area that requires further research.

Whilst none of the studies to date are of sufficient sample size to detect a significant difference in infection rates with the use of intra-articular catheters, similar catheter techniques are employed during epidural analgesia for postoperative pain relief in other types of surgery (e.g., abdominal), and infection does not appear to be an issue.

\section{What Is the Optimal Infiltration Site?}

One of the next stages in the evolution of local infiltration techniques is to try and identify the optimum site of administration of the local anaesthetic. In their randomised study Andersen et al. [36] observed no difference between the use of intracapsular catheters or intra-articular catheters in total knee arthroplasty with ropivacaine infusion. In a randomised, placebo-controlled, double-blind trial investigating the role of subcutaneous wound infiltration (all patients received high volume local infiltration to the deeper layers), the same authors reported a significant reduction in both 
static and dynamic pain scores at 24 hours in the group that received intraoperative subcutaneous infiltration [24]. However, bolus administration through a subcutaneously placed catheter at 24 hours was ineffective. These observations support their previously published observations of a tendency (not statistically significant) towards improved pain relief with the addition of local anesthetic in the extraarticular wound space [25].

\section{What Is the Most Effective Dose?}

The use of ropivacaine instead of bupivacaine enables larger doses of local anaesthetic to be delivered to the joint and the surrounding tissues whilst minimising the risk of toxicity. The addition of adrenaline as part of the multimodal infiltration technique also enables higher doses of local anaesthetic to be used and may also potentiate the duration of action of the local anaesthetic by slowing its release into the vascular system. Only 2 studies were identified in which plasma ropivacaine levels were measured $[14,17]$. This gave a combined total of 27 patients. Whilst this number is small, all patients remained below toxic levels.

There are no studies to date looking at the optimal doses for infiltration or infusion/bolus. In general, all of the studies identified adopted a standardised LIA regimen for all patients rather than tailoring doses to individual weights. It is possible that by matching ropivacaine dose to the individual a better response can be achieved. In addition, in the future the use of sustained-release local anaesthetics may negate the need for intra-articular catheters [38].

\section{Local Infiltration versus Epidural}

Continuous epidural analgesia following hip and knee arthroplasty is an effective method of providing predictable and reliable pain relief in the early postoperative period. However, it is technically demanding and time-consuming and may be associated with an array of side effects that include urinary retention, hypotension, headache, motor blockade, and nausea, all of which may result in delayed mobilisation.

The appeal of local infiltration techniques lies with the fact that they are inexpensive and relatively easy to perform, and have few side effects. Whilst we have reviewed the evidence for the use of such techniques when compared to a placebo (in which one may expect the LIA to perform better), the question remains as to how they compare to epidural infusion.

There have been several studies to date comparing the use of local infiltration techniques to epidural infusion [26-29]. All of these support the use of local infiltration showing equal or better pain relief, earlier mobilisation, and reduced length of stay when compared to epidural infusion. However, as there is no clearly defined gold standard epidural regimen, these results should be interpreted with caution. This is a fact acknowledged by Andersen et al. in their randomised controlled trial of patients undergoing total knee arthroplasty [28].

\section{Local Infiltration versus Peripheral Nerve Block}

In many institutions femoral nerve block forms part of the standard postoperative pain relief protocols following total knee arthroplasty [30,39]. So how does local infiltration compare to this? There is little published in the literature comparing these two analgesic modalities. Whilst Toftdahl et al. [30] observed lower pain scores and opioid consumption with earlier mobilisation with inta-articular infiltration in their randomized trial, Carli et al. [31] observed the opposite, concluding that femoral nerve block was the most effective modality. In their randomized trial, Affas et al. [32] observed no significant difference in either pain intensity in the first 24 hours, or opiate consumption, between local infiltration anaesthesia and continuous femoral block. They postulated, however, that LIA may be considered to be superior to femoral nerve block due to the fact that it is both cheaper and less technically demanding. However, it should be noted that in their study Toftdahl et al. [30] observed a couple of adverse events in the LIA group, again highlighting that further research is needed in this area. Also, as with the studies on epidural anaesthesia what constitutes a femoral nerve block varies between studies making comparisons difficult.

\section{Summary}

There is a growing body of evidence to support the use of local infiltration anaesthesia as part of enhanced recovery pathways in patients undergoing knee replacement surgery. The evidence for its role in hip replacement surgery is less compelling. Despite the growing body of literature, there remain many unanswered questions. These observations are also supported by the recent review by Kehlet and Andersen [40] which approaches the same subject from a different perspective.

Different patients have different responses to analgesia due to their preoperative response to pain [41]. This can be predicted by using preoperative pain tests. The solution may be to use these tests to customise the analgesia for each patient and so achieve enhanced recovery. The goal should be to use the minimum dose for every patient (based on both weight and pain response). This is the area further research needs to focus upon.

Future research should also focus upon standardisation of outcome measures so that different analgesic approaches can be more easily compared. Cost analysis should also be looked at.

\section{References}

[1] H. Kehlet and D. W. Wilmore, "Evidence-based surgical care and the evolution of fast-track surgery," Annals of Surgery, vol. 248, no. 2, pp. 189-198, 2008.

[2] H. Husted and G. Holm, "Fast track in total hip and knee arthroplasty-experiences from Hvidovre University Hospital, Denmark," Injury, vol. 37, no. 5, pp. S31-S35, 2006. 
[3] S. O’Brien, L. Ogonda, S. J. Dennison et al., "Day two post operative "fast-track" discharge following primary total hip replacement," Journal of Orthopaedic Nursing, vol. 9, no. 3, pp. 140-145, 2005.

[4] L. Basse, D. H. Jakobsen, P. Billesbølle, M. Werner, and H. Kehlet, "A clinical pathway to accelerate recovery after colonic resection," Annals of Surgery, vol. 232, no. 1, pp. 51-57, 2000.

[5] A. V. Maheshwari, Y. C. Blum, L. Shekhar, A. S. Ranawat, and C. S. Ranawat, "Multimodal pain management after total hip and knee arthroplasty at the ranawat orthopaedic center," Clinical Orthopaedics and Related Research, vol. 467, no. 6, pp. 1418-1423, 2009.

[6] A. Rodgers, N. Walker, S. Schug et al., "Reduction of postoperative mortality and morbidity with epidural or spinal anaesthesia: results from overview of randomised trials," British Medical Journal, vol. 321, no. 7275, pp. 1493-1497, 2000.

[7] S. C. Urwin, M. J. Parker, and R. Griffiths, "General versus regional anaesthesia for hip fracture surgery: a meta-analysis of randomized trials," British Journal of Anaesthesia, vol. 84, no. 4, pp. 450-455, 2000.

[8] L. S. Rasmussen, T. Johnson, H. M. Kuipers et al., "Does anaesthesia cause postoperative cognitive dysfunction? A randomised study of regional versus general anaesthesia in 438 elderly patients," Acta Anaesthesiologica Scandinavica, vol. 47, no. 3, pp. 260-266, 2003.

[9] M. J. Parker, H. H. Handoll, and R. Griffiths, "Anaesthesia for hip fracture surgery in adults," Cochrane Database of Systematic Reviews, no. 4, article CD000521, 2004.

[10] T. J. Luger, C. Kammerlander, M. Gosch et al., "Neuroaxial versus general anaesthesia in geriatric patients for hip fracture surgery: does it matter?" Osteoporosis International, vol. 21, no. 4, pp. S555-S572, 2010.

[11] J. E. Paul, A. Arya, L. Hurlburt et al., "Femoral nerve block improves analgesia outcomes after total knee arthroplasty: a meta-analysis of randomized controlled trials," Anesthesiology, vol. 113, no. 5, pp. 1144-1162, 2010.

[12] E. R. Bogoch, M. Henke, T. Mackenzie, E. Olschewski, and N. N. Mahomed, "Lumbar paravertebral nerve block in the management of pain after total hip and knee arthroplasty: a randomized controlled clinical trial," Journal of Arthroplasty, vol. 17 , no. 4 , pp. 398-401, 2002.

[13] B. Ben-David, K. Schmalenberger, and J. E. Chelly, "Analgesia after total knee arthroplasty: is continuous sciatic blockade needed in addition to continuous, femoral blockade?" Anesthesia and Analgesia, vol. 98, no. 3, pp. 747-749, 2004.

[14] P. A. Vendittoli, P. Makinen, P. Drolet et al., "A multimodal analgesia protocol for total knee arthroplasty: a randomized, controlled study," Journal of Bone and Joint Surgery A, vol. 88, no. 2, pp. 282-289, 2006.

[15] D. R. Kerr and L. Kohan, "Local infiltration analgesia: a technique for the control of acute postoperative pain following knee and hip surgery-A case study of 325 patients," Acta Orthopaedica, vol. 79, no. 2, pp. 174-183, 2008.

[16] L. J. Anderson, T. Poulsen, B. Krogh, and T. Nielsen, "Postoperative analgesia in total hip arthroplasty: a randomised double-blinded, placebo-controlled study on peroperative and postoperative ropivacaine, ketorolac, and adrenaline wound infiltration," Acta Orthopaedica, vol. 78, pp. 187-192, 2007.

[17] C. A. Busch, B. J. Shore, R. Bhandari et al., "Efficacy of periarticular multimodal drug injection in total knee arthroplasty: a randomized trial," Journal of Bone and Joint Surgery A, vol. 88, no. 5, pp. 959-963, 2006.

[18] P. Essving, K. Axelsson, J. Kjellberg, O. Wallgren, A. Gupta, and A. Lundin, "Reduced morphineconsumption and pain inten- sity with local infiltration analgesia (LIA) following total knee arthroplasty: a randomized double-blind study involving 48 patients," Acta Orthopaedica, vol. 81, no. 3, pp. 354-360, 2010.

[19] P. Gómez-Cardero and E. C. Rodríguez-Merchán, "Postoperative analgesia in TKA: ropivacaine continuous intraarticular infusion," Clinical Orthopaedics and Related Research, vol. 468, no. 5, pp. 1242-1247, 2010.

[20] B. A. Krenzel, C. Cook, G. N. Martin, T. P. Vail, D. E. Attarian, and M. P. Bolognesi, "Posterior capsular injections of ropivacaine during total knee arthroplasty: a randomized, doubleblind, placebo-controlled study," Journal of Arthroplasty, vol. 24, no. 6, pp. 138-143, 2009.

[21] L. O. Andersen, H. Husted, K. S. Otte, B. B. Kristensen, and H. Kehlet, "High-volume infiltration analgesia in total knee arthroplasty: a randomized, double-blind, placebo-controlled trial," Acta Anaesthesiologica Scandinavica, vol. 52, no. 10, pp. 1331-1335, 2008.

[22] S. Zhang, F. Wang, Z. D. Lu, Y. P. Li, L. Zhang, and Q. H. Jin, "Effect of single-injection versus continuous local infiltration analgesia after total knee arthroplasty: a randomized, doubleblind, placebocontrolled study," Journal of International Medical Research, vol. 39, no. 4, pp. 1369-1380, 2011.

[23] D. W. Chen, P. H. Hsieh, K. C. Huang, C. C. Hu, Y. H. Chang, and M. S. Lee, "Continuous intra-articular infusion of bupivacaine for post-operative pain relief after total hip arthroplasty: a randomized, placebo-controlled, double-blind study," European Journal of Pain, vol. 14, no. 5, pp. 529-534, 2010.

[24] L. O. Andersen, H. Husted, B. B. Kristensen, K. S. Otte, L. Gaarn-Larsen, and H. Kehlet, "Analgesic efficacy of subcutaneous local anaesthetic wound infiltration in bilateral knee arthroplasty: a randomised, placebo-controlled, double-blind trial," Acta Anaesthesiologica Scandinavica, vol. 54, no. 5, pp. 543-548, 2010.

[25] L. O. Andersen, B. B. Kristensen, H. Husted, K. S. Otte, and H. Kehlet, "Local anesthetics after total knee arthroplasty: intraarticular or extraarticular administration? A randomized, double-blind, placebo-controlled study," Acta Orthopaedica, vol. 79, no. 6, pp. 800-805, 2008.

[26] U. J. Spreng, V. Dahl, A. Hjall, M. W. Fagerland, and J. Ræder, "High-volume local infiltration analgesia combined with intravenous or local ketorolac and morphine compared with epidural analgesia after total knee arthroplasty," British Journal of Anaesthesia, vol. 105, no. 5, pp. 675-682, 2010.

[27] K. V. Andersen, M. Pfeiffer-Jensen, V. Haraldsted, and K. Søballe, "Reduced hospital stay and narcotic consumption, and improved mobilization with local and intraarticular infiltration after hip arthroplasty: a randomized clinical trial of an intraarticular technique versus epidural infusion in 80 patients," Acta Orthopaedica, vol. 78, no. 2, pp. 180-186, 2007.

[28] K. V. Andersen, M. Bak, B. V. Christensen, J. Harazuk, N. A. Pedersen, and K. Søballe, "A randomized, controlled trial comparing local infiltration analgesia with epidural infusion for total knee arthroplasty," Acta Orthopaedica, vol. 81, no. 5, pp. 606-610, 2010.

[29] M. Thorsell, P. Holst, H. C. Hyldahl, and L. Weidenhielm, "Pain control after total knee arthroplasty: a prospective study comparing local infiltration anesthesia and epidural anesthesia," Orthopedics, vol. 33, no. 2, pp. 75-80, 2010.

[30] K. Toftdahl, L. Nikolajsen, V. Haraldsted, F. Madsen, E. K. Tönnesen, and K. Søballe, "Comparison of peri- and intraarticular analgesia with femoral nerve block after total knee arthroplasty: a randomized clinical trial," Acta Orthopaedica, vol. 78, no. 2, pp. 172-179, 2007. 
[31] F. Carli, A. Clemente, J. F. Asenjo et al., "Analgesia and functional outcome after total knee arthroplasty: periarticular infiltration vs continuous femoral nerve block," British Journal of Anaesthesia, vol. 105, no. 2, pp. 185-195, 2010.

[32] F. Affas, E.-B. Nygrds, C.-O. Stiller, P. Wretenberg, and C. Olofsson, "Pain control after total knee arthroplasty: a randomized trial comparing local infiltration anesthesia and continuous femoral block," Acta Orthopaedica, vol. 82, no. 4, pp. 441-447, 2011.

[33] S. Sharma, R. Iorio, L. M. Specht, S. Davies-Lepie, and W. L. Healy, "Complications of femoral nerve block for total knee arthroplasty," Clinical Orthopaedics and Related Research, vol. 468, no. 1, pp. 135-140, 2010.

[34] T. Röstlund and H. Kehlet, "High-dose local infiltration analgesia after hip and knee replacement-What is it, why does it work, and what are the future challenges?" Acta Orthopaedica, vol. 78, no. 2, pp. 159-161, 2007.

[35] H. Kehlet and S. S. Liu, "Continuous local anaesthetic wound infusion to improve post-operative outcome: back to the periphery?" Anaesthesiology, vol. 107, pp. 369-371, 2007.

[36] L. O. Andersen, H. Husted, B. B. Kristensen, K. S. Otte, L. Gaarn-Larsen, and H. Kehlet, "Analgesic efficacy of intracapsular and intra-articular local anaesthesia for knee arthroplasty," Anaesthesia, vol. 65, no. 9, pp. 904-912, 2010.

[37] C. Stein, K. Comisel, E. Haimerl et al., "Analgesic effect of intraarticular morphine after arthroscopic knee surgery," New England Journal of Medicine, vol. 325, no. 16, pp. 1123-1126, 1991.

[38] J. L. Pedersen, J. Lillesø, N. A. Hammer et al., "Bupivacaine in microcapsules prolongs analgesia after subcutaneous infiltration in humans: a dose-finding study," Anesthesia and Analgesia, vol. 99, no. 3, pp. 912-918, 2004.

[39] T. Wainwright and R. Middleton, "An orthopaedic enhanced recovery pathway," Current Anaesthesia and Critical Care, vol. 21, no. 3, pp. 114-120, 2010.

[40] H. Kehlet and L. O. Andersen, "Local infiltration analgesia in joint replacement: the evidence and recommendations for clinical practice," Acta Anaesthesiologica Scandinavica, vol. 55, no. 7, pp. 778-784, 2011.

[41] M. U. Werner, H. N. Mjöbo, P. R. Nielsen, and A. Rudin, "Prediction of postoperative pain: a systematic review of predictive experimental pain studies," Anesthesiology, vol. 112, no. 6, pp. 1494-1502, 2010. 


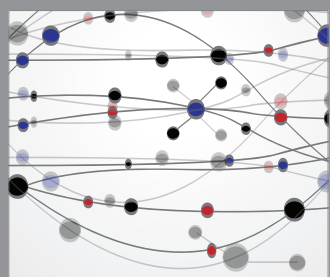

The Scientific World Journal
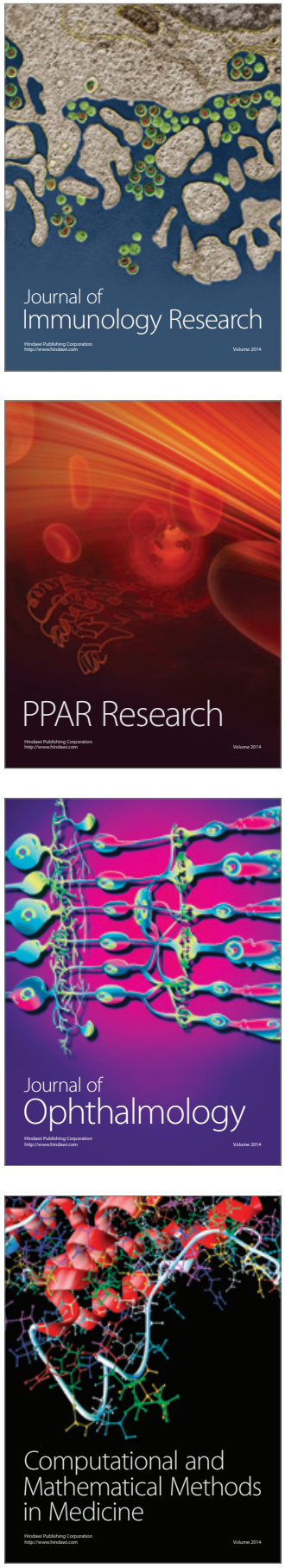

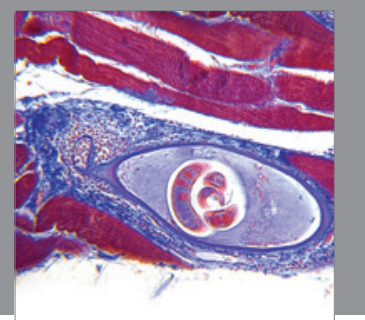

Gastroenterology

Research and Practice
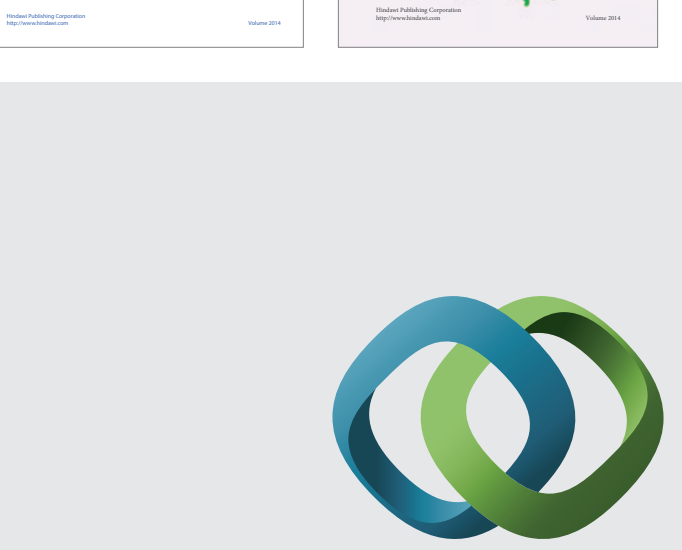

\section{Hindawi}

Submit your manuscripts at

http://www.hindawi.com
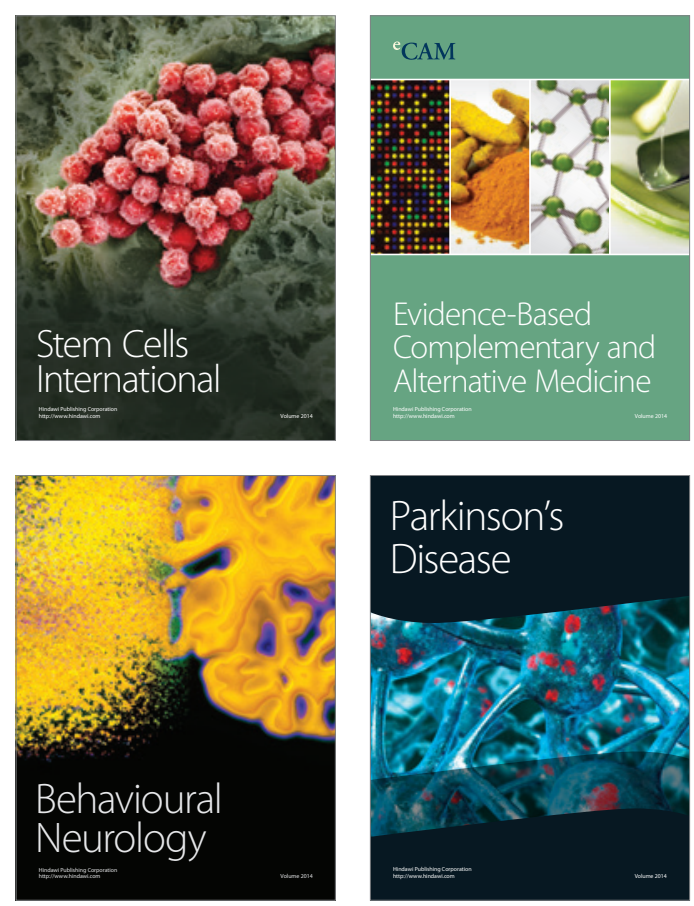

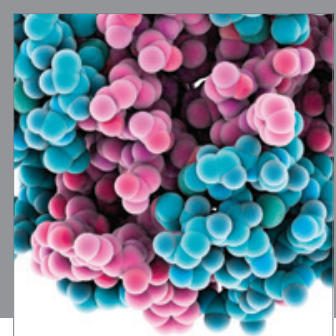

Journal of
Diabetes Research

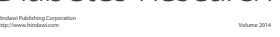

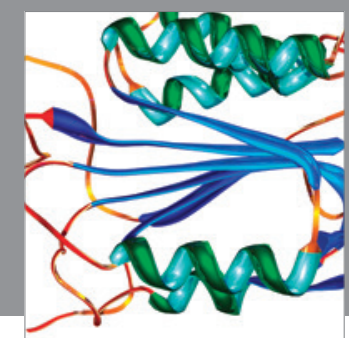

Disease Markers
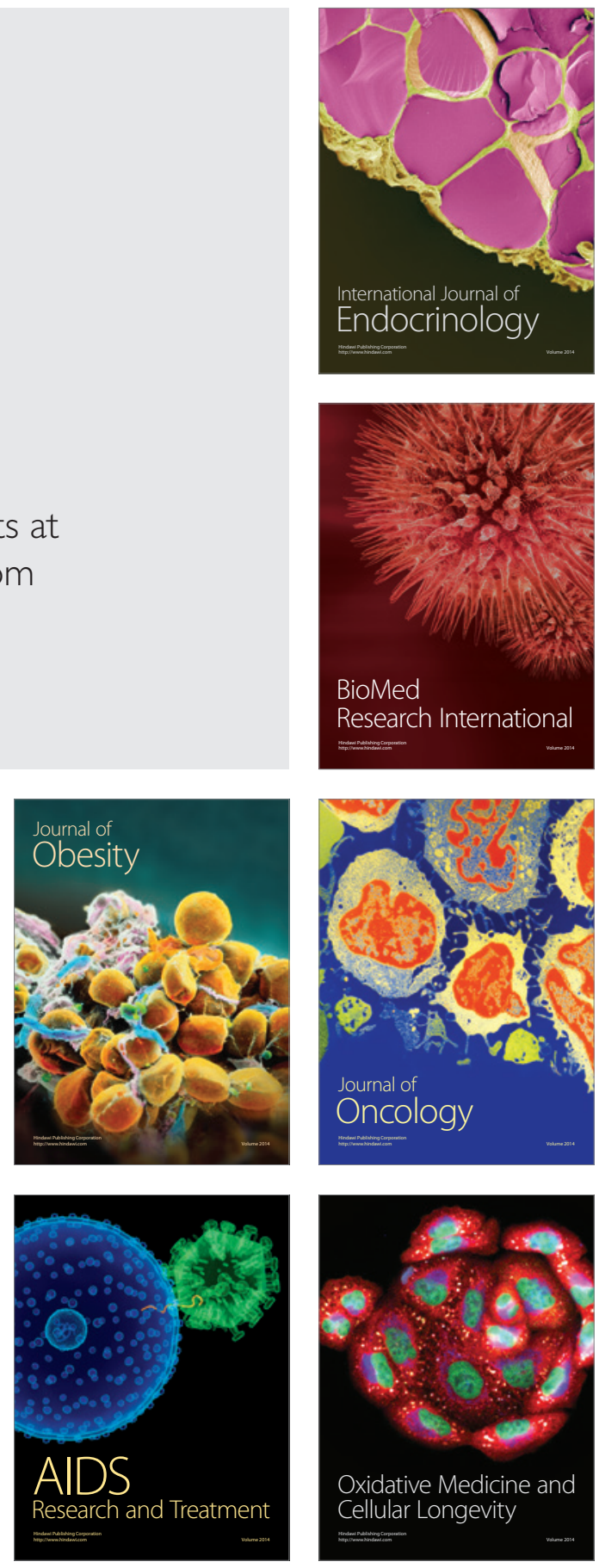